\title{
Bank Size, Risk and Market Discipline with a Deposit Insurance: Evidence of Banking in Indonesia
}

\section{Sugeng Haryanto ${ }^{1}$, Grahita Chandrarin ${ }^{2}$, and Yanuar Bachtiar ${ }^{3}$}

\author{
${ }^{1}$ Diploma3 Finance and Banking University of Merdeka Malang \\ Jl. Terusan Raya Dieng No. 57, Malang, 65146, Indonesia \\ ${ }^{2}$ Graduate School Universitas of Merdeka Malang \\ Jl. Terusan Raya Dieng No. 59, Malang, 65145, Indonesia \\ 2STIE Indonesia Banjarmasin \\ Jl. Brig Jend. Hasan Basri No.9 - 11, Banjarmasin, 70124, Indonesia
}

\section{Info Artikel}

Keywords:

Bank risk; Bank size; Deposite insurance; Market discipline

ISSN (print) : 2598-7763 ISSN (online): 2598-7771

\footnotetext{
$\square$ Corresponding Author: Sugeng Haryanto: Tel. /Fax. 081332373081

E-mail:

sugeng.haryanto@unmer.ac.id
}

\begin{abstract}
Abtract
The Indonesian banking system has implemented a deposit guarantee. Deposit guarantees are carried out in order to provide a sense of security for customers. Moral hazard tends to be higher in the banking industry This study aims to examine the relationship of bank characteristics with market discipline. Bank characteristics include: capital, bank risk, profitability, efficiency and bank size. The population in this study is banks in Indonesia. The sample selection uses a purposive sampling method. The number of samples of 30 banks with peroide 2009-2015. Data analysis techniques used multiple linear regression. The results showed the profitability and size of the bank affect market discipline. Where profitability and bank size have a positive effect on market discipline. This research has implications for the importance of banks in increasing bank assets, especially for private banks.
\end{abstract}

Citation: Haryanto, Sugeng, Chandrarin, Grahita and Bachtiar, Yanuar (2019). Bank Size, Risk and Market Discipline with a Deposit Insurance: Evidence of Banking in Indonesia. Accounting and Financial Review, 2 (2)

\begin{abstract}
Abstraks
Sistem perbankan Indonesia telah menerapkan penjaminan deposito. Penjaminan deposito dilakukan dalam rangka memberikan rasa aman bagi nasabah. Moral hazard cenderung lebih tinggi pada industri perbankan Penelitian ini bertujuan untuk menguji hubungan karakteristik bank dengan disiplin pasar. Karakteristik bank meliputi: permodalan, risiko bank, Profitabilitas, efisiensi dan ukuran bank. Populasi dalam penelitian ini adalah bank di Indonesia. Pemilihan sampel menggunakan metode purposive sampling. Jumlah sampel 30 bank dengan peroide 2009-2015. Teknik analisis data digunakan regresi linerar berganda. Hasil penelitian menunjukkan profitabilitas dan ukuran bank berpengaruh terhadap disiplin pasar. Dimana profitabilitas dan ukuran bank berpengaruh positif terhadap disiplin pasar. Penelitian ini memberikan implikasi pentingnya bank dalam meningkatkan asset bsank, terutama bagi bank swasta.
\end{abstract}

JEL Classification: E43, G28

DOI: https://doi.org/10.26905/afr.v2i2.3717

\section{INTRODUCTION}

Bank is a financial institution which has a very strategic role whereas the structure of the Indonesian financial industry in 2015 was still dominated by banks consisting of Commercial Banks and Rural Credit Banks (BPR). This could be seen from the total assets of the banking industry towards financial institutions which reached $78.2 \%$. The ratio of credit to GDP in Indonesia in 2014 was around 36\% (Bank Indonesia, 2014). As the intermediary function of financial institutions, banks also have a market share of 80 percent in financing (credit) from the intermediation func- 
tion of the entire financial system (Astohar, 2009).

The bank financial intermediary function arises as the results of high liquidity costs, monitoring costs, and price risk. This arising occurs because there is asymmetric information between the owner of the fund (household) and the company using the funds (corporations/net borrowers) so that an intermediary is needed to be able to accommodate the needs of both parties (Haryanto, 2015).

The banking industry will be able to perform the intermediation function properly and efficiently if the bank is healthy. Sound banking is essential for sustaining and supporting a healthy and strong economy (Hasan and Tandelilin, 2012). In order to strengthen national banking, the Indonesian bank adopted the International Convergence of Capital Measurement and Capital Standards: A Revised Framework document, better known as the Basel II Framework which was published by the BCBS (Basel Committee on Banking Supervision) in June 2004 and the revised edition in June 2006. There are 3 (three) complementary pillars, namely Minimum Capital Requirements, Supervisory Review Process and Market Discipline.

Changes in business complexity and the risk profile originating from banks or from subsidiary companies, and changes in the assessment of bank conditions which are applied internationally affect the bank sound assessment approach. Bank soundness is a means for the supervisory authority to determine the strategy and focus of supervision on banks assessing the soundness of banks. According to PBI: 13/1/PBI/2011, the health rating of banks has changed based on the risk with the scope of assessment are 1) risk profile, 2) Good Corporate Governance (GCG), 3) earnings, and 4) capital.

The banking industry will be able to perform the intermediation function properly and efficiently if the bank is healthy. Sound banking is essential for sustaining and supporting a healthy and strong economy (Hasan and Tandelilin, 2012). In order to strengthen national banking, the Indonesian bank adopted the International Convergence of Capital and in order to improve supervision, transparency is an important aspect in efforts to strengthen banks. Transparency is very much needed in the banking world, bearing in mind that the depositors and investors have interest in the security and management of their funds (Hasan, 2013). This mechanism of supervision on risk and bank performance by market participants is what is called market discipline. Market discipline is a control carried out by the community to increase trust. Market discipline is the level of concern of the general public and the people, who are banking customers, about the conditions being faced by banks, more specifically banks that are directly related to customers' savings and investment funds (Jati and Murni, 2012).

Market discipline is a series of three pillars, in addition to minimum capital standards and regulatory processes to improve the security and soundness of the banking and financial system. Market discipline is one of the important pillars of sound banking (Hasan and Tandelilin, 2012). This is because market discipline provides incentives for banks to conduct their business with safe, good and efficient behavior. Market discipline encourages the public role to participate in supervising banks (Riandika and Taswan, 2015).

The existence of a deposit insurance institution has an impact on customer behavior. Market discipline will tend to decrease when the guarantees given are greater (Ioannidou and Dreu, 2006; Karas, Pely and Schoors, 2019). The existence of LPS in that context is to provide guarantees for customer funds.

The competitive environment will influence the banking industry. In developed countries with open information and intense competition among banks, market discipline tends to occur more often. Thus, there is an automatic control between the public and the banking industry. Research in a country where the banking industry has advanced, such as in the United States, shows that depositors, both those with savings funds and those who are without, will monitor and control effective banking (Goldber and Hudgins, 1996; Park and Peristiani 1998; Khorassani, 2000; Goldber and Hudgins 2002), in Switzerland (Birchler and Maechler 2002), and in Indonesia (Widyastuti, et. al., 2019), In these circumstances, the reward and punishment mechanism works flawlessly, not only depositors who care about the world banking, but the banking industry will also be more concerned with the level of risk encountered and will be directly related to the security of customer funds.

The debate over market discipline is interesting when it meets with different conditions and regulations of the banking industry where market discipline function is acting as the control for bank stakeholders. In Indonesia, Bank Indonesia policies tend to have the potential for an oligopolistic banking industry (Taswan, 2011). 
Hadad et al. (2011) examined the market discipline in Indonesia within the period of 1995 to 2009 with grounded changes to regulations concerning collateral for customer deposits and bank capital. This research was conducted with the changing regulatory environment regarding the bank health paradigm. Bank health assessment that previously applied was Bank Indonesia Regulation (PBI) No. 6/10 / PBI/2004 concerning the Rating System for Commercial Banks referring to CAMELS. Bank Indonesia Regulation (PBI): 13/1/PBI/2011 dated 5 January 2011 concerning Rating of Soundness of Commercial Banks has changed the risk-based rating of banks in Indonesia, known as RGEC.

Several studies conducted in developing countries show that the depositor has the ability to discipline banks (Martinez and Schmukler (2001). This is certainly interesting because in developing countries there is less public awareness. The results of this study are possible because this study precisely was performed in developing countries during the period of high bank risk research, so that public discipline will be high. This study aims to analyze the influence of bank capital, risk, liquidity, profitability, efficiency, and bank size towards market discipline.

\section{HYPOTHESIS DEVELOPMENT}

Financial institutions have experienced rapid and complex development, so market discipline is needed. Market discipline is an important part of efforts to create sound banking (Meyer, 1999). Market discipline to reduce the burden of supervision of financial institutions (Bliss, 2005). Market discipline mechanism is where market participants monitor and discipline excessive risktaking behavior by banks (Lane, 1993; Stephanou, 2010; Ahmad, et. al., 2019). Thus, market discipline is a monitoring mechanism by market participants for risk and bank performance.

There are several studies used changes in volume of deposits as an indicator of market discipline; they are Park \& Peristiani (1998), and Jagtiani \& Lemieux (2001). Other researchers used interest ratios and changes in deposit volumes as indicators of market discipline; they are Ellis \& Flannery (1992) and Cook \& Spellman (1994). Taswan (2011) and Riandika and Taswan (2015) used deposit growth as an indicator of market discipline. Two market discipline measures, namely the ratio of deposit changes (FUND) and the ratio of deposit interest fees to total deposits were used by Taswan (2013).

Bank capital, in this case, Capital Adequacy Ratio (CAR) is an important pillar for banks. The role of capital is very important in the banking business because it can support the bank operational activities, so that it can run smoothly (Sari, 2013). CAR is a capital ratio that shows the ability of banks to provide funds for business development needs and to accommodate the risk of loss of funds caused by bank operations. CAR is a ratio that takes into account how much all the bank assets that contain risks which are financed from their own capital funds, funds from sources outside the bank, such as public, loans (debt) and others.

CAR shows the ability of the bank financial resources that can be used for business development needs and to anticipate potential losses from credit channeled. The greater the CAR of a bank shows that the bank is increasingly solvable. Banks with high CAR will be stronger in bearing the risk of any credit or productive assets that are at risk and able to finance bank operations. A large CAR ratio indicates that bank capital is also large, so that banks will have the flexibility to place funds from that capital for productive asset portfolios (Haryanto, 2014).

Banks that are able to fulfill CAR show that bank complies with banking regulations. Banks that are increasingly compliant with regulations show that the bank is healthy. One measure of bank health is related to CAR. Banks with high CAR indicate that the bank is much healthier. Bank Indonesia determines bank CAR provisions are above $8 \%$. Banks that have a greater CAR are a positive signal for depositors, and conversely, the lower CAR is a negative signal, the consequence is depositors will withdraw their savings.

Banks with a higher CAR have the ability to absorb risk. In addition, banks with high CAR will be able to create a healthy banking system that is able to develop and compete nationally and internationally. Research by Skully et. al. (2012), Riandika and Taswan (2015) found that CAR had a positive effect on driving deposit growth. The finding of Irfan and Nugroho (2015) was that CAR had a negative effect on changes in deposits.

$\mathrm{H}_{1}$ : Capital Adequacy Ratio (CAR) of banks influences market discipline.

Changes in the bank business environment are rapid. Both external and internal environment will be followed by increasingly complex risks for banking business activities. The bank is a business 
with a high level of risk. One of the risks that arises due to the increasingly complex banking activities is the emergence of a larger Non-Performing Loan (NPL) (Haryanto, 2016a). NPL is one indicator to see the ability of bank management to manage extended loans. The higher the NPL of a bank indicates that the ability of management is getting worse which indicates the worse quality of credit. Conversely, a lower NPL shows the ability of bank management to improve credit, so that the quality of assets is getting better. NPL is a comparison between total non-performing loans and total loans distributed to debtors. NPL is a ratio that reflects credit risk, where the higher the NPL, the greater the credit risk borne by the bank (Haryanto, 2014). The higher NPL will increase costs, as well as for the provision of productive assets and other costs that is conversely smaller. The higher the NPL shows the higher the problem loans of a bank (Haryanto, 2016 ${ }^{\text {b }}$ ).

NPL information is one of the bases used by the public to assess how a bank is performing. The higher the NPL indicates the ability of management to manage loans that tends to get worse, so that the greater the risk of banks tends to make people reluctant to save their funds. This is related to the risk of funds.

Hadad et. al (2011) in his research on Market Discipline, Financial Crisis, and Regulatory Change stated that an evidence from Indonesia Banks using credit risk to measure bank risk showed that bank risk positively influenced market discipline. The results of Jatna's research (2007) showed that the public had utilized the availability of information in the form of problem loans as a basis for assessing the performance of a bank. Apart of that, the guaranteed interest rate indicator was also used by depositors as one of its considerations in depositing funds in banks. Skully (2012), Jati and Murni (2012) research results showed that the NPL ratio had a significant negative effect on deposit growth. Riandika and Taswan (2015) found that NPLs did not affect market discipline.

$\mathrm{H}_{2}$ : Non-Performance Loan (NPL) affects Market Discipline.

Banks are required to be able to perform good liquidity management. Liquidity is used as a collateral for possible payment obligations. Some banks carry out strategies with excess liquidity as a signal to the market that the bank has strong liquidity. However, such high liquidity can also be interpreted that banks have poor liquidity management so that they are not managing their portfolio of assets and liabilities optimally (Wuryandani et al, 2014). Hasan and Tandelilin research results (2012) showed positive depositor reactions on Net Interest Margin (NIM) and positive depositor reactions to Loan to Deposit Ratio (LDR).

$\mathrm{H}_{3}$ : Loan to Deposit Ratio (LDR) affects Market Discipline

Profitability is the most appropriate indicator to measure bank performance (Sofyan: 2013). Bank Indonesia prioritizes the value of a bank profitability as measured by the value of assets whose funds mostly come from public funds or deposits. ROA is used to measure the efficiency and effectiveness of a company in generating profits by utilizing its assets. The high ROA indicates that banks are getting better at using their assets. Banks with good profitability have shown that the bank fundamentals are good. The results of Barajas and Steiner (2000) stated that depositors preferred banks with strong fundamentals. Riantika (2015) stated that ROA had a positive effect on deposit growth.

$\mathrm{H}_{4}$ : Profitability (ROA) affects Market Discipline

High competition, including in the banking industry, tends to create efficiency. Efficiency is a very important determinant in the activities of a company. Efficiency in the banking industry as a whole is an important aspect to consider to create a healthy and sustainable bank performance (Abidin and Endri, 2009). Under conditions of the increasing fierce competition today, banks are required to be able to be efficient in their operations.

Efficiency is a very important factor in business, because efficiency is one of the important indicators to measure the overall performance of a company activities. Hence, the company will always try to improve its efficiency. Wheelock and Wilson (1999) stated that efficiency was an important measure of a bank operational conditions and was one of the key indicators of a bank success.

$\mathrm{H}_{5}$ : Efficiency affects Market Discipline

The size of the company shows the size of assets owned by the bank, the number of sales, average total sales and average assets. The size of the company shows the amount of experience and ability to grow a company that indicates the ability and level of risk in managing investments provided by the stockholders to increase investor prosperity (Haryanto, 2015). A larger company will be relatively more stable and more capable of 
generating profits than a company with small total assets (Pangemanan and Mawikere, 2011). This shows that large companies are more promising for good performance (Lin 2006). Trust is a very important capital for a bank. Public confidence will tend to increase in banks with good performance. Consequently, the public (depositors) tend to save their funds in large banks because depositors tend to trust them more.

$\mathrm{H}_{6}$ : Bank size influences market discipline

\section{DATA AND METHODS}

The population in this study was banks in

Table 1. Variable Operationalization

\begin{tabular}{lll}
\hline No & \multicolumn{1}{c}{ Varible } & \multicolumn{1}{c}{ variable operationalization } \\
\hline 1 & Market Discipline & Changes in deposits Ratios \\
2 & Bank Capital & Capital Aqequacy Ratio (CAR) \\
3 & Risk & Non Performance Loans (NPL) \\
4 & Likuidity & Loan to deposit ratio (LDR) \\
5 & Profitability & Return on Assets \\
6 & Efficiency & Operating Costs on Operating Income (BOPO) \\
7 & Size & Assets \\
\hline
\end{tabular}

Data collection techniques were carried out with documentation and data analysis techniques were used to determine the effect of capital variables, risks, liquidity, profitability, efficiency and bank size on market discipline, either partially or simultaneously using multiple linear regression. To eliminate the size of different variables, the multiple regression equation model was formulated as follows:

$$
Y=\beta_{1} X_{1}+\beta_{2} X_{2}+\beta_{3} X_{3}+\beta_{4} X_{4}+\beta_{5} X_{5}+e
$$

Where: Y: Market discipline; b1-5: Regression coefficient; X1: Bank capital measured by the value of the Capital Adequacy Ratio (CAR); X2: Bank risk measured from Non-Performance Loans (NPLs); X3: Liquidity measured from Loan to Deposit Ratio (LDR); X4: Bank profitability measured by ROA; X5: Bank efficiency; X6: Bank size; and e: Error
Indonesia. The sampling technique in this study was purposive sampling; the determination of samples with certain criteria following the objectives of the study. The criteria used are 1) the bank had gone public on the Indonesia Stock Exchange before 2009; 2) the bank published its 2009-2015 financial statements. Based on the sampling technique, the number of companies entering the sample was 30 banks. The source of data used secondary data taken from http: idx.co.id. The type of data was in the form of quantitative data and in the form of financial statement data.

\section{RESULT}

\section{Data description}

A description of the research data for 30 banks within the period of 2009 to 2015 analysis range was presented in Table 2. Based on Table 2, it showed that the average deposits deposited by banks continue to increase, but this increase was not evenly experienced by all banks. Large banks tend to increase deposits. Bank capital as indicated by the average CAR of banks during the period of 2009 to 2015 was above the Bank Indonesia regulation ( $8 \%$ ). The credit risk shown by the NPL had fluctuated, but the average was still below Bank Indonesia regulations, which was 5 percent. The low NPL showed that national bank credit management was quite good.

Table 2. Data Description

\begin{tabular}{lrrrrrrr}
\hline & 2009 & 2010 & 2011 & 2012 & 2013 & 2014 & 2015 \\
\hline Deposits & 68,354 & 81,846 & 91,691 & 107,761 & 124,716 & 138,104 & 135,446 \\
CAR & 16.95 & 15.94 & 15.79 & 15.86 & 16.22 & 16.36 & 17.62 \\
NPL & 3.14 & 3.42 & 2.67 & 2.29 & 2.17 & 2.73 & 2.60 \\
LDR & 70.68 & 71.84 & 77.71 & 77.94 & 85.66 & 85.77 & 86.79 \\
ROA & 1.26 & 1.63 & 1.79 & 1.88 & 1.72 & 1.47 & 1.31 \\
Efficiency & 84.24 & 82.55 & 81.43 & 77.90 & 83.26 & 84.82 & 86.65 \\
Assets & 81,647 & 98,390 & 118,060 & 137,544 & 158,041 & 182,469 & 200,102 \\
\hline
\end{tabular}


Profitability shows the ability of management to manage banks; the better management in managing the bank, the higher the profitability will be. Bank profitability (ROA) during the period of 2009 to 2015 showed fluctuating values. Based on ROA values, it showed that banks in Indonesia were healthy. Bank efficiency was shown by the value of efficiency during the study period ranging from $77.9 \%$ to $86.65 \%$. The higher the efficiency value, it indicates the lower the bank efficient level. The level of bank efficiency, in general, was still good, because it was still within the range of Bank Indonesia regulations. The increase in efficiency partly influenced by the increase in the cost of funds. The increase in deposits had a significant impact on the increase in bank assets. The increase in bank assets was in line with the increase in bank deposits during the period of 2009 to 2015.

Table 3. Summary of Data Analysis Results

\section{Goodness Fit of Model Testing}

By testing the goodness of models, namely by testing simultaneously the effect of capital variables, bank risk, liquidity, profitability, efficiency and company size on the market discipline showed a calculated $F$ value of 87.793 with a probability $\mathrm{F}$ of 0.000 . The probability value was smaller than 0.05 , so that a decision could be taken that the independent variables affected the market discipline simultaneously in the national banking industry (Table 3). The coefficient of determination was adjusted ( $\mathrm{R}^{2}$ adjusted) which was indicated by the value of $\mathrm{R}^{2}$ adj. amounted to 0.747 . This showed that the independent variables shown by capital, bank risk, liquidity, profitability, efficiency and company size could explain the market discipline variance of $74.7 \%$, while the remaining $25.3 \%$ was explained by other variables outside the model.

\begin{tabular}{|c|c|c|c|c|}
\hline Variabel & $\begin{array}{l}\text { Standardized } \\
\text { Coefficients Beta }\end{array}$ & $\mathrm{t}$ & Sig. & VIF \\
\hline CAR & -0.070 & -1.777 & 0.077 & 1,080 \\
\hline NPL & -0.074 & -1.711 & 0.089 & 1,311 \\
\hline LDR & -0.016 & -0.425 & 0.671 & 1,027 \\
\hline ROA & 0.097 & 2.208 & 0.029 & 1,352 \\
\hline Efficiency & 0.014 & 0.350 & 0.727 & 1,143 \\
\hline Size & 0.803 & 18.535 & 0.000 & 1,306 \\
\hline $\mathrm{R}^{2}$ & $: 0.756$ & & & \\
\hline $\mathrm{R}^{2}{ }_{\mathrm{Adj}}$ & $: 0.747$ & & & \\
\hline $\mathrm{F}$ & : 87.793 & & & \\
\hline $\mathrm{F}_{\text {Prob }}$ & : 0.000 & & & \\
\hline DW & : 2.035 & & & \\
\hline
\end{tabular}

\section{DISCUSSION}

\section{Effect of Capital on Market Discipline}

The results showed that bank capital did not affect market discipline. Bank capital measured by CAR value is the ability of banks to bear the risk of each credit. The results of this study indicated that the public perceived the capital of banks in Indonesia was quite healthy. This was indicated by the average CAR value was above Bank Indonesia regulation $8 \%$ (Table 1). Therefore, even though the bank CAR value fluctuated, the fluctuation was still in a safe condition, which was above $8 \%$. When CAR fluctuates, customers or the public are not worried as long as followed by taking action to withdraw funds. A decrease in the value of CAR is not perceived by customers as a decrease in the health of the bank as long as the decrease in CAR value is still within the limits of Bank Indonesia regulations. Conversely, when a bank CAR increases, it does not necessarily mean that customers or the public will add more deposit to their savings in the bank. This is because high CAR value does not directly affect customers. A high CAR value makes customer psychological relatively calm.

The results of this study did not support the findings of research conducted by Skully et. al. (2012), Riandika and Taswan (2015) who found that CAR had a positive effect on encouraging deposit growth. This study also did not support the research of Irfan and Nugroho (2015) where CAR could harm changes in deposits.

\section{The Effect of Credit Risk on Market Discipline}

NPL is the ratio between problem loans and bank loans. This ratio is used to measure credit risk whereas the higher the NPL shows the higher the risk faced by banks. The results showed that NPL did not affect market discipline. The results of this study indicated that customers or the public were not so affected by the ability of 
banks to manage the extended loans. This situation was supported by the fact that the average value of non-performing loans (NPL) of banks was quite good, whereas the value of future NPLs was below 5\%. Nevertheless, there are several banks with high NPL values. If the NPL value is already very high, the customer certainly will respond by withdrawing funds as a form of minimizing the risk of the funds.

The bank risk variable, in this case the NPL value to market discipline, is also supported by the existence of a customer deposit guarantee system, namely the existence of LPS. The existence of LPS more or less will make sense of security for customers and the public in depositing funds in the bank. The existence of a customer deposit guarantee system tends to weaken market discipline. The results of this study supported the findings of a study conducted by Riandika and Taswan (2015) wherein NPL did not affect market discipline. However, this study did not support the findings of research conducted by Jatna (2007), Skully (2012), Jati and Murni (2012) in which showed that the NPL ratio had a significant negative effect on deposit growth.

\section{The Effect of Liquidity on Market Discipline}

Bank liquidity shows the ability to meet short-term obligations. This bank obligation can be in the form of a credit request or a withdrawal of depositors from their funds. Bank liquidity, as measured by LDR, is quite vulnerable and can be suddenly drained from a bank if trust in a bank decreases. The results showed that liquidity had no effect on market discipline. Banks with high LDR showed lower bank liquidity, and vice versa.

The results of this study indicated that customers did not respond to changes in bank liquidity. This was possible because the average level of bank liquidity was still quite good wherein the average LDR value during the period of 2009 to 2015 was ranging from $70.68 \%$ to $86.79 \%$. Therefore, the bank liquidity was not seen by customers as something worrisome. This was what made customers less likely to influence market discipline. The results of this study did not support the research findings of Hasan and Tandelilin (2012).

\section{The Effect of Profitability on Market Discipline}

Profitability is an important measure of a bank health. Besides profitability also potrays the ability of management in managing a bank. The higher the profitability of a bank shows that the better the performance. ROA shows the level of ability of banks to generate profits. The higher ROA shows the bank ability to generate profits from assets owned by the bank. ROA is a bank profitability indicator that is preferred over other profitability indicators. The results showed that ROA affected market discipline in a positive direction. This shows that the motives of customers or the public in depositing funds to the bank tend to be about how the health and prospects of the bank going forward. This is certainly related to a sense of security for customers of the funds they hold. In a fierce bank competition, the health of the bank with profitability as an indicator becomes important for customers. Customers will tend to save their funds in banks with a good level of health and conversely customers tend to avoid banks whose health is not well. This result also indicated that the public in saving their funds tended to see how profitability or fundamentals one bank is. The results of this study supported the research findings of Barajas and Steiner (2000), Riandika and Taswan (2015) wherein ROA had a positive effect on deposit growth.

\section{The Effect of Efficiency on Market Discipline}

The results of the study on the effect of bank efficiency, which was proxied by BOPO on market discipline, showed that efficiency did not affect market discipline. These results indicated that community control through market discipline was not influenced by the efficiency of a bank. The efficiency of a bank, whether it is high or low for the community, is not that important. Thus, people do not really respond in the form of savings in a bank. This condition may be caused by the depositor view that whether the bank is efficient or not, they assume that this will not affect the costs or interest incurred or earned. Although, the development of efficiency showed an increase wherein the average bank efficiency was ranging from 77.26 to 86.65 within the period of 2009 to 2015. This efficiency value was above the efficiency of banks in ASEAN countries. In addition, the average depositor deposit was not too large, or even the public felt that there was no other choice but to deposit their excess funds, which caused the depositor did not respond to the efficiency of a bank. Although, efficiency does not affect market discipline, it does not mean that banks do not suppress their efficiency in order to increase the bank efficiency. This is because efficiency is an important measure of bank operational conditions and is one of the key indicators of a bank success (Wheelock and Wilson, 1999). 


\section{The Effect of Bank Size on Market Discipline}

The results showed that bank size influenced market discipline in a positive direction. This shows that banks with an increasingly large size, as measured by assets owned, tend to be chosen by the public or customers in depositing funds. People feel more confident in saving money in large banks compared to small banks. Banks with large assets tend to be able to open networks with branches in various regions. This will certainly make it easier for the public to deposit their funds in the bank compared to banks with fewer networks.

Banks with large networks will be more in touch with their customers, making it easier for customers to deal (transaction) with these banks. In addition, banks with large assets tend to have better ability and experience in managing banks, so customers tend to have more trust. Trust is the main capital and is very important in the banking business. Large companies are more promising for good performance.

These results indicated that the public tends to believe that large banks are less likely to be closed by the government. The community believes that large banks do not get to be shut down because the impact will be large. Findings from Yudistira (2002) found that people behavior in Indonesia tended to shift from small banks to large banks.

\section{CONCLUSIONS AND SUGGESTIONS}

The results showed that simultaneous capital, bank risk, liquidity, profitability, efficiency, and bank size affected market discipline. Partially it showed that capital, bank risk, liquidity, and efficiency did not affect market discipline, variable profitability and bank size affected market discipline instead.

The object of this study was limited to the national banking industry that went public with an analysis span of 2009 to 2015 with a sample of 30 banks. The variables used to predict market discipline were only the capital, bank risk, liquidity, profitability, efficiency, and bank size variables. For further research, it can be done by analyzing the banking industry by classifying banks with assets and the number of bank branches. Variables for other variables, both internal and external factors of the bank, are carried out as predictors of market discipline.

\section{REFERENCES}

Abidin, Zaenal, dan Endri, (2009). Kinerja Efisiensi Teknis Bank Pembangunan Daerah: Pendekatan Data Envelopment Analysis (DEA). Jurnal Akuntansi dan Keuangan. 11 (1)

Ahmad, R.L., Febrian, E., Anwar, M., and Herwany, A., (2019). Market Discipline and Implicit Deposit Protection Empirical Study on the Regional Development Banks in Indonesia. Journal of Economics and Economic Education Research, Research Article: 201920 (2)

Astohar. (2009). Analisis Faktor yang Mempengaruhi Profitabilitas Perbankan Di Indonesia (Studi Pada Bank Domestik, Bank Campuran dan Bank Asing). Tesis. Universitas Diponegoro Semarang (unpublished).

Bank Indonesia. 2014. Statitik Ekonomi Keuangan Indonesia.

Barajas, A \& Steiner, R. (2000). Depositor behavior and market discipline in Colombia. Working Paper. No.wp/00/214. International Monetary Fund. Washington DC

Bliss, Robert R. (2005). Market Discipline: Players, Processes, And Purposes In Market Discipline Accros Countries And Industries. Blackwell publishing

Bliss, Robert R., and Mark Flannery. (2002). Market Discipline In The Governance Of U.S. Bank Holding Companies: Monitoring Vs Influence. European Finance Review, 6 (3)

Birchler, Urs W. and Andrea M. Maechler. (2002). Is there Market Discipline in Swiss banks? In Research in Financial Services, Prompt Corrective Action in Banking: 10 Years Later. 14: 243-257.

Cook, D. \& Spellman, L. (1994). Repudiation Risk and Restitution Costs: Toward Understanding Premiums on Insured Deposits. Journal of Money, Credit, and Banking, 26 (3): 439459.

Ellis, D. \& Flannery, M. (1992). Does the Debt Market Assess Large Banks' Risk? Journal of Monetary Economics, 30 (3)

Goldberg, Lawrence G., and Sylvia C. Hudgins. (1996). Response of Uninsured Depositors to Impending S \& L Failures: Evidence of Depositor Discipline. Quarterly Review of Economics and Finance 36: 311-325

Hadad, M.D., Agusman, A., Monroe, G.S., Gasbarro, D., Zumwalt, J.K., (2011). Market discipline, financial crisis and regulatory 
changes: Evidence from Indonesian banks. Journal of Banking and Finance 35

Haryanto, Sugeng. (2016a). Determinan Permodalan Bank Melalui Profitabilitas, Risiko, Ukuran Perusahaan, Efisiensi dan Struktur Modal. Jurnal Ekonomi dan Bisnis (JEB). 19 (1)

Haryanto, Sugeng. (2016b). Profitability Identification of National banking Through Credit, Capital, Capital Structure, Effeciency, and Risk Level. Jurnal Dinamika Manajemen (JDM). 7 (1)

Haryanto, Sugeng. (2015). Determinan Struktur Modal. Proceeding Strtegic Agility: Thrive in Turbulent Environment (Research and Practices). Jurusan manajemen FE Unnes. 7 Oktober 2015.

Haryanto, Sugeng. (2015). Determinan Capital Buffer: Kajian Empirik Industri Perbankan Nasional. Jurnal Ekonomi Modernisasi. 11 (2)

Haryanto, Sugeng. (2014). Identifikasi Ekspektasi Investor Melalui Kebijakan Struktur Modal, Profitabilitas, Ukuran Perusahaan dan CGPI. Jurnal Dinamika Manajemen JDM. 5 (2)

Hasan dan Tandelilin, Eduardus. (2012). Banking Market Dicipline in Indonesia an Empirical Test on Conventional and Islamic Banks. Journal of Indonesia Economy and Business. 27 (2)

Hasan. (2013). Meningkatkan Transparansi dan Disiplin pasar Perbankan Syariah Di Indonesia. Jurnal Economica. IV (1)

Ioannidou, V and Jan de Dreu, d.J., (2006). The Impact of Explicit Deposit Insurance on Market Discipline. DNB Working Paper No. 089/2006

Irfan and Nugroho, Anggoro Budi. (2015). Market Discipline: Empirical Survey on Indonesia Government Domestic Bank. World Journal of Social Sciences. 5 (3)

Jagtiani, J. \& Lemieux, C. (2001). Markets Discipline Prior to Failure. Journal of Economics and Business $53(2 / 3)$

Jati, Dian Purnomo. dan Murni, Sri. (2012). Disiplin pasar, Krisis Perbankan dan Penjaminan Sipanan (Studi Kasus Perbankan Indonesia). Jurnal Performance. 16 (2)

Jatna, M., (2007). Pengujian Efektivitas Market Disipline (Disiplin pasar) Pada Bank Umum di Indonesia dengan Balanced Panel Data Estimation [Test of Market Discipline Effectiveness on Commercial Bank in Indonesia with Balanced Panel Data Esti- mation. Thesis of Master Program. Yogyakarta: Faculty of Economics and Business, Universitas Gadjah Mada

Karas, A., Pyle, W., and Schoors, K., (2019). Deposit Insurance, Market Discipline and Bank Risk. U.S.E. Research Institute Working Paper Series 19-02

Khorassani, J. (2000). An Empirical Study of Depositor Sensitivity to Bank Risk. Journal of Economics and Finance. 24(1), 15-27.

Lane, Timothy D. (1993). Market Discipline. Staff Papers - International Monetary Fund, Vol. 40 (1).

Martinez Peria, MS \& Schmukler, SL. (2001). Do depositors Punish Banks for Bad Behavior? Market Discipline, Deposit Insurance, and Banking Crises. Journal of Finance. 56 (3)

Meyer, Laurence H. (1999). Market Discipline as a Complement to Bank Supervision and Regulation. Remarks Before the Conference on Reforming Bank Capital Standards. Council on Foreign Relations. New York. June 14.

Pangemanan, S., dan L. Mawikere. (2011). Pengaruh Ukuran Perusahaan dan Pertumbuhan Perusahaan terhadap Earning Per share pada Industri Tekstil di Bursa Efek Indonesia. Jurnal Riset Akuntansi dan Auditing Goodwill. 2 (1).

Park, S. \& Peristiani, S. (1998). Market Discipline by Thrift Depositors. Journal of Money, Credit, and Banking, 30 (3)

Riandika, Aditya Febri dan Taswan. (2015). Pengujian Disiplin pasar Perbankan Berdasarkan Posisi CAR, LDR, ROA dan NPL. Prosiding Seminar Nasional Multi Disiplin Ilmu $\mathcal{E}$ Call For paper Unisbank

Sari, Yulimel. (2013). Pengaruh Profitabilitas, Kecukupan Modal dan Likuiditas Terhadap Harga Saham (Perusahaan Perbankan yang Terdaftar di BEI). Jurnal Akuntansi. 1 (1)

Skully, Michael et.al,. (2012). Market Discipline And The Australian Deposit Guarantee: Banks Versus Mutuals

Sofyan, S. (2013). Keputusan Go Public dan Hubungannya dengan Bank-Bank Swasta di Indonesia. Jurnal Media Riset \& Manajemen. 3 (1) April.

Stephanou, Constantinos. (2010). Rethinking Market Discipline in Banking Lessons from the Financial Crisis. The World Bank Policy Research Working Paper 5227

Taswan. (2013). Pengujian Empiris Disiplin Pasar Periode Penjaminan Simpanan Implisit dan 
Eksplisit Di Indonesia. Jurnal Keuangan dan Perbankan. 17 (2)

Taswan. (2011). Kepemilikan Bank, Kepatuhan Regulasi dan Disiplin Pasar : Kontrol Risiko Perbankan dan Moral Hazard Terkait Posisi Charter Value Pada Periode Penjaminan Simpanan Implisit dan Eksplisit. Ringkasan Disertasi Ujian Terbuka dan Promosi Doktor Fakultas Ekonomika dan Bisnis Universitas Gadjah Mada.

Taswan. (2011). Kebijakan Modal Minimum, Kepemilikan Tunggal dan Kebijakan Penyalahgunaan Posisi Dominan Dalam Persaingan Usaha Industri Perbankan. Jurnal Benefit. 15 (2)

Wheelock, DC dan Wilson, P. (1999). Technical Progress Inefdiciency and Productivity Change in U.S. Banking 1984-1993. Journal of Money, Credit and Banking 31.

Widyastuti, Ratna Sri dan Armanto, Boedi. (2013). Kompetisi Industri Perbankan Indonesia. Buletin Ekonomi Moneter dan Perbankan. April 2013.

Widyastuti, U., Febrian, E., Sutisna, and Fitrijanti, T. (2019). Factors Explaining the Market Discipline of Sharia Mutual Funds from a Behavioural Finance Perspective: A Theoretical Approach. International Journal of Economics and Business Administration, 7 (3): 198-212

Wuryani, Gantiah. (2014). Pengelolaan Dana dan Likuiditas Bank. Buletin Ekonomi Moneter dan Perbankan. Januari 2014

Yudistira, D., (2002). The Impact of Bank Capital Requirements in Indonesia. Working Paper, Loughborough University. 